\title{
EFFECT OF NORMAL PRESSURE ON GLACIER SLIDING
}

\section{(Abstract only)}

\author{
by \\ Roger L. Hooke \\ (Department of Geology and Geophysics, University of Minnesota, Minneapolis, \\ Minnesota 55455, U.S.A.)
}

ABSTRACT

Mercury is used to force a block of ice, measuring $0.20 \times 0.45 \mathrm{~m}$ in area and $0.20 \mathrm{~m}$ in height, over an irregular bed. Normal and shear stresses on the bed can be varied up to 15 and $3 \times 10^{5} \mathrm{~Pa}$ respectively, so the apparatus permits a full-scale simulation of sliding of a $150 \mathrm{~m}$ thick glacier over irregularities a few tens of millimeters in height.

Preliminary results of an experiment in which ice slid over a bed consisting of two streamlined bumps, roughly $15 \mathrm{~mm}$ in height, suggest that sliding velocity is independent of normal pressure in the absence of cavitation. This is consistent with existing theoretical models of glacier sliding (Weertman 1964, Kamb 1970, Lliboutry 1979), but is not consistent with the experimental results of Budd and others (1979). Further studies are needed to determine the reasons for this disagreement.

\section{REFERENCES}

Budd W F, Keage P L, Blundy N A 1979 Empirical studies of ice sliding. Journal of GLaciology 23(89): 157-170

Kamb W B 1970 Sliding motion of glaciers: theory and observations. Review of Geophysics and Space Physics 8(4): 673-728

Lliboutry L A 1979 Local friction laws for glaciers: a critical review and new openings. Journal of Glaciology 23(89): $67-95$

Weertman $\mathrm{J} 1964$ The theory of glacier sliding. Joumal of Glaciology 5(39): 287-303 